\title{
Glosa do wyroku Wojewódzkiego Sądu Administracyjnego w Poznaniu z dnia 30 stycznia 2014 r. I SA/Po 1107/13
}

\section{Tezy:}

1. „(...) Kolegium RIO w P. trafnie wskazało w zaskarżonej uchwale, że dokonywanie przesunięć wydatków między działami budżetu gminy jest w istocie zmianą tego budżetu, a uprawnienie do dokonania tej czynności, podobnie jak uchwalenie budżetu, należy do wyłącznej kompetencji organu stanowiącego gminy, czyli Rady. (...) W ocenie Sądu, przeniesienie wydatków w taki sposób nie jest wbrew twierdzeniom strony skarżącej - wykonywaniem budżetu gminy, ale jego zmianą, a to oznacza, że takie działanie leży poza zakresem uprawnień organu wykonawczego gminy. Podkreślenia w tym miejscu jeszcze raz wymaga, że ustawodawca jednoznacznie wykluczył możliwość dokonywania w budżecie gminy przesunięć przez organ wykonawczy pomiędzy działami budżetu, co wynika z treści art. 258 ust. 1 pkt 1 u.f.p. Organ wykonawczy może natomiast dokonywać przesunięć wydatków pomiędzy rozdziałami i paragrafami budżetu, jeżeli uzyska na to upoważnienie od rady gminy." 
2. „Ponadto podnieść należy, że choć przesuwane środki pochodziły z rozdziału 75818 «Rezerwy ogólne i celowe», a zgodnie z art. 221 ust. 4 u.f.p. zarząd jednostki samorządu terytorialnego dokonuje podziału rezerw, o których mowa w ust. 1 i 2, a więc rezerwy ogólnej i rezerwy celowej, to okoliczność ta - wbrew twierdzeniom strony skarżącej - w analizowanej sprawie nie ma żadnego znaczenia. Wskazać bowiem należy, że organ wykonawczy może dokonać podziału rezerw celowych wyłącznie wtedy, gdy wcześniej rada utworzy nowe zadanie (cel), na które rezerwa celowa zostanie przez organ wykonawczy rozdysponowana.”

\section{1.}

W szerokim kontekście analizowane orzeczenie dotyczy rezerw celowych w budżecie jednostki samorządu terytorialnego (j.s.t.) oraz zasad ich rozdysponowania przez organ wykonawczy. W szczególności kwestią, która podlegała rozstrzygnięciu przez Wojewódzki Sąd Administracyjny w Poznaniu, była możliwość ustanowienia w budżecie miasta nowego zadania majątkowego (inwestycyjnego) przez Burmistrza w oparciu o środki z zaplanowanej rezerwy celowej w planie wydatków.

Problematyka funkcjonowania rezerw w budżecie j.s.t. była przedmiotem szeregu opracowań naukowych oraz orzeczeń sądowych. Regulacje z tego zakresu w obecnie obowiązującej ustawie o finansach publicznych $^{1}$ nie podlegały jakimś radykalnym zmianom w porównaniu z ustawą o finansach publicznych z roku $2005^{2}$, choć z drugiej strony nie można też abstrahować od kilku istotnych modyfikacji przepisów dokonanych przez ustawodawcę ${ }^{3}$. Wydawać by się więc mogło, że instytucja ta ugruntowała się w praktyce gospodarki finansowej samorządów i nie powinna wywo-

1 Ustawa z dnia 27 sierpnia 2009 r. o finansach publicznych (tekst jedn. Dz.U. z 2013 r., poz. 885 ze zm., dalej: u.f.p.).

2 Ustawa z dnia 30 czerwca 2005 r. o finansach publicznych (Dz.U. Nr 249, poz. 2104 ze zm.).

3 Modyfikacje te polegały m.in. na: wprowadzeniu obligatoryjności tworzenia rezerwy ogólnej oraz określeniu jej minimalnego poziomu (poziom maksymalny się nie zmienił), uporządkowaniu i uszczegółowieniu przepisów dotyczących rezerw celowych, zmianie redakcyjnej odnoszącej się do rozdysponowywania limitów rezerw. Zob. szerzej w E. Ruśkowski, J.M. Salachna (red.), Finanse publiczne. Komentarz praktyczny, Gdańsk 2014, s. 993. 
ływać większych wątpliwości. Tak jednak nie jest, czego przykładem jest glosowane orzeczenie. W pewnej mierze występujące problemy mają swoje źródło w pomijaniu istoty rezerw budżetowych, czy nawet w niezrozumieniu tych instytucji, do czego autor jeszcze nawiąże w dalszej części tekstu.

\section{2.}

Stan faktyczny analizowanego orzeczenia odnosił się do jednej ze zmian w budżecie miasta, jakie zostały wprowadzone przez Burmistrza. Mianowicie w załączniku nr 2 zarządzenia - „Plan wydatków majątkowych na 2013 r.” dokonał on rozdysponowania środków z rezerwy celowej, zmniejszając wydatki (a dokładniej mówiąc - limity wydatków) w dziale 758 - „Rozliczenia różne”, rozdział 75818 - „Rezerwy ogólne i celowe”, a następnie przeniósł je do działu 754 - „Bezpieczeństwo publiczne i ochrona przeciwpożarowa”, rozdział 75416 - „Straż gminna (miejska)”, w którym wprowadził nowe zadanie majątkowe pod nazwą „wykonanie przyłącza do fotoradaru i montaż masztu do fotoradaru”. Jako podstawa prawna powoływanego zarządzenia zostały wskazane art. 257 pkt 1 i 3 u.f.p. oraz art. 222 u.f.p.

Powyższa czynność została zakwestionowana przez regionalną izbę obrachunkową (RIO) w postępowaniu nadzorczym. Wskazała ona na istotne naruszenie prawa, tj. art. 18 ust. 2 pkt 4 ustawy z dnia 8 marca o samorządzie gminnym ${ }^{4}$ i stwierdziła nieważność zarządzenia w części, która dotyczyła podziału rezerwy celowej. Kolegium RIO argumentowało, że art. 257 u.f.p. nie uprawnia Burmistrza Miasta do dokonywania zmian polegających na ustanawianiu nowych zadań majątkowych w budżecie jednostki. Ponadto podkreśliło, że stosownie do art. 258 ust. 1 pkt 1 u.f.p. istnieje możliwość rozszerzenia zakresu zmian dokonywanych przez organ wykonawczy w budżecie na podstawie upoważnienia organu stanowiącego, ale z wyłączeniem przeniesień między działami klasyfikacji 4 Ustawa z dnia 8 marca 1990 r. o samorządzie gminnym (tekst jedn. Dz.U. z 2013 r.,
poz. 594 ze zm., dalej: u.s.g.). 
budżetowej. Kolegium izby zauważyło, że zgodnie z upoważnieniem zawartym w § 11 pkt 3 uchwały budżetowej Rada Miasta upoważniła Burmistrza do dokonywania zmian planu wydatków majątkowych, ale tylko w odniesieniu do już uchwalonych przez nią zadań, ujętych w załączniku do uchwały budżetowej pt. „Plan wydatków majątkowych na 2013 r.”. Z dokładnego brzmienia § 11 pkt 3 uchwały budżetowej wynika, że Rada Miasta upoważniła Burmistrza do „dokonywania zmian planu wydatków $\mathrm{w}$ ramach działu w zakresie wydatków majątkowych do kwoty [...] zł w ramach każdego zadania”.

Tym samym dokonując zmian w wydatkach majątkowych poprzez utworzenie nowego zadania ,wykonanie przyłącza do fotoradaru i montaż masztu do fotoradaru”, Burmistrz naruszył przepis art. 18 ust. 2 pkt 4 u.s.g. Z argumentacji tej wynika więc, iż przekroczył on zakres udzielonego mu upoważnienia do zmian w budżecie, wkraczając w kompetencje Rady Miasta.

W skardze do WSA w Poznaniu na uchwałę nadzorczą Burmistrz Miasta wskazał na naruszenie następujących przepisów prawa materialnego poprzez niewłaściwe ich zastosowanie: art. 222 ust. 4 u.f.p., art. 257 u.f.p., art. 258 u.f.p., art. 259 ust. 1 i 2 u.f.p., art. 60 ust. 1 pkt 5 u.s.g., art. 18 ust. 2 pkt 4 u.s.g. Odnosząc się do tych przepisów, przytoczył szereg argumentów na poparcie swego stanowiska. Po pierwsze, zarzucił Kolegium RIO, że w rozstrzygnięciu nadzorczym nie odniosło się do wszystkich przepisów, które potencjalnie mogły mieć zastosowanie w sprawie, w szczególności do art. 222 ust. 4 u.f.p. Po drugie, tworząc rezerwę celową na wydatki majątkowe, Rada Miasta nie sprecyzowała, jakie mają być te wydatki. Na tej podstawie skarżący dowodził, że sam podział rezerwy należy do sfery wykonywania budżetu i na podstawie art. 222 u.f.p. był on uprawniony do realizacji takiej czynności. Natomiast czym innym jest jak dalej wskazywał - zmiana przeznaczenia rezerwy celowej zgodnie z trybem określonym w art. 259 ust. 2 u.f.p. Zdaniem Burmistrza utworzenie nowego zadania w ramach środków pochodzących z rezerwy celowej, przy jednoczesnym braku ograniczenia Rady Miasta co do możliwości jej wykorzystania, jest rozdysponowaniem tej rezerwy na cel, na jaki 
została utworzona zgodnie z art. 259 ust. 1 u.f.p., a więc leży to w jego kompetencji.

Po trzecie, w opinii skarżącego organ nadzoru w analizowanej sprawie błędnie zastosował przepisy art. 257 i 258 u.f.p. oraz art. 18 ust. 2 pkt 4 u.s.g. Podstawą rozstrzygnięcia powinny tu być art. 222 i 259 ust. 1 u.f.p. oraz art. 60 ust. 2 pkt 5 u.s.g. Wynika z nich wyłączne prawo organu wykonawczego do dysponowania rezerwami budżetowymi, które należy rozumieć jako zmianę wydatków budżetu prowadzącą do przeniesienia (pomniejszenia) środków rezerwy i jednoczesnego powiększenia wydatku istniejącego lub zaplanowania wydatku nowego.

Ostatecznie WSA w Poznaniu nie przyznał racji skarżącemu i skargę oddalił. Uznał, że skarga nie zasługuje na uwzględnienie. Zarzuty wobec uchwały nadzorczej RIO, zdaniem sądu, nie znajdują podstawy w prawie materialnym, nie naruszono także przepisów prawa procesowego.

\section{3.}

Wobec powyższych argumentów RIO oraz tez sądu administracyjnego wynikających z uzasadnienia analizowanego orzeczenia, należy się odnieść krytycznie. Przy czym dla rozwiązania zasadniczego problemu wskazanego na początku glosy, tj. możliwości kreowania nowych zadań (wydatków majątkowych) w oparciu o środki rezerwy celowej, autor rozpatrzy następujące zagadnienia szczegółowe: właściwość podstawy prawnej rozdysponowania środków rezerwy celowej, wykonywanie budżetu j.s.t. a jego zmiana $\mathrm{w}$ trakcie roku budżetowego w kontekście dysponowania rezerwą celową, rozdysponowanie rezerwy celowej a kreowanie nowych zadań (wydatków).

Na uwagę zasługuje zarzut Burmistrza Miasta w odniesieniu do uchwały Kolegium RIO polegający na tym, iż nie odniosło się ono do wszystkich przepisów, które miały zastosowanie w sprawie, a w szczególności chodziło o art. 222 ust. 4 u.f.p. Przepis ten ustala kompetencje organu wykonawczego j.s.t. do dokonywania podziału rezerw budżetowych (ogólnej i celowych). Z uzasadnienia orzeczenia wynika, że organ nadzoru w ogóle go nie uwzględnił przy ocenie legalności działań Burmi- 
strza w przedmiocie rozdysponowania rezerwy celowej, a właściwej podstawy prawnej doszukiwał się w art. 257 pkt 1 i 3, art. 258 ust. 1 pkt 1 u.f.p. oraz w przepisach uchwały budżetowej zawierających szczegółowe upoważnienia Rady Miasta do wykonania określonych czynności przez Burmistrza. Na tej podstawie stwierdzono naruszenie kompetencji organu stanowiącego do uchwalania budżetu określonej w art. 18 ust. 2 pkt 4 u.s.g. Sąd z kolei stwierdził, że art. 222 ust. 4 u.f.p. w analizowanej sprawie nie ma żadnego znaczenia, bowiem podział rezerwy celowej z przeznaczeniem na nowe zadanie mógłby zostać dokonany wyłącznie wówczas, gdyby wcześniej zdanie takie Rada utworzyła w budżecie jednostki.

Szczególnie niezrozumiała $\mathrm{w}$ tym aspekcie jest argumentacja RIO. Instytucja przeniesień wydatków, o której stanowią przepisy art. 257 pkt 1 i 3 oraz art. 258 § 1 pkt 1 u.f.p. w ogóle nie ma zastosowania do czynności podziału środków rezerw budżetowych (zarówno ogólnej, jak i celowych), co wynika z istoty tej instytucji. Po pierwsze, środki zgromadzone w ramach rezerw w planie wydatków planowanymi wydatkami nie są, w odróżnieniu od pozostałych środków ujętych w poszczególnych podziałkach klasyfikacji budżetowej, a stanowią zapasowe nieskonkretyzowane limity wydatków ${ }^{5}$. Po drugie, rozdysponowanie rezerwy nie jest typową czynnością przeniesienia wydatków, a należy ją uznać za czynność powiększenia limitu określonego rodzaju wydatku, a ściślej rzecz ujmując, przekształcenia na skonkretyzowany limit wydatku ${ }^{6}$. Po trzecie, ograniczenia przenoszenia wydatków pomiędzy działami, o których mowa w art. 257 pkt 3 i art. 258 § 1 pkt 1 u.f.p., w żadnym wypadku nie odnosi się do rezerw budżetowych. Każde bowiem działanie polegające na podziale środków zgromadzonych w rezerwach sprowadza się do zmniejszenia wydatku (limitu wydatku) jednego działu, tj. działu 758 - „Różne rozliczenia” (w ramach którego występuje rozdział 75818 - „Rezerwy ogólne i celowe”) i jednoczesnym powiększeniu o tę samą kwotę limitu wydatku znajdującego się w innym dziale. Gdyby ograniczenia wynikające z powoły-

5 J.M. Salachna, Dokonywanie zmian w uchwale budżetowej jednostki samorzqdu terytorialnego, [w:] J.M. Salachna (red.), Budżet samorzqdowy $i$ wieloletnia prognoza finansowa - projektowanie, wykonywanie, sprawozdawczość, Gdańsk 2014, s. 342-343.

6 Tamże, s. 342. 
wanych przepisów miały zastosowanie do rezerw, w ogóle nie można byłoby korzystać ze środków w nich zgromadzonych, a więc instytucja ta pozostałaby martwa. W tym kontekście całkowicie błędne należy uznać twierdzenie Sądu pojawiające się w orzeczeniu, że „ustawodawca jednoznacznie wykluczył możliwość dokonania w budżecie gminy przesunięć przez organ wykonawczy pomiędzy działami budżetu, co wynika z treści art. 258 ust. 1 u.f.p.”. W przypadku rezerw budżetowych działanie takie jest jak najbardziej legalne i znajduje swoje podstawy w art. 222 ust. 4 u.f.p., art. 60 ust. 2 pkt 5 u.s.g oraz wynika z przyporządkowania rezerw budżetowych odrębnemu działowi w strukturze klasyfikacji budżetowej ${ }^{7}$.

Ponadto w ocenie Sądu przeznaczenie środków z rezerwy celowej przez Burmistrza Miasta na nowe zadanie majątkowe pt. „wykonanie przyłącza do fotoradaru i montaż masztu do fotoradaru” nie było wykonywaniem budżetu, ale jego zmianą. W konsekwencji działanie to leżało poza zakresem uprawnień Burmistrza jako organu wykonawczego jednostki. Sąd zgodził się ze stanowiskiem Kolegium RIO, że dokonanie przesunięcia wydatków pomiędzy działami budżetu j.s.t. jest w istocie zmianą tego budżetu, a uprawnienie do wykonania tej czynności należy do wyłącznej kompetencji organu stanowiącego. Tym samym w analizowanej sprawie doszło do naruszenia art. 18 ust. 2 pkt 4 u.s.g.

$\mathrm{Z}$ powyższym uzasadnieniem Sądu trudno się zgodzić. Biorąc pod uwagę ogół przepisów ustawy o finansach publicznych i ustawy o samorządzie gminnym, a także uwzględniając charakter prawny budżetu, wyznaczanie ścisłej granicy pomiędzy zmianą budżetu a jego wykonywaniem nie jest do końca właściwe. Oba procesy - zmiana budżetu i jego wykonywanie - są niejednokrotnie ze sobą ściśle powiązane. Ekonomiczno-zarządzeniowy charakter planu finansowego, jakim jest budżet publiczny, sprawia że plan ten musi posiadać określony stopień elastyczności, co w konsekwencji przekłada się na kształt regulacji prawnych. Na ich podstawie organ wykonawczy j.s.t. w pewnym zakresie posiada kompetencje do zmiany budżetu, które pozostają w związku z jego wykonywaniem.

7 Rozporządzenie Ministra Finansów z dnia 2 marca 2010 r. w sprawie szczegółowej klasyfikacji dochodów, wydatków, przychodów i rozchodów oraz środków pochodzących ze źródeł zagranicznych (tekst jedn. Dz.U. z 2014 r., poz. 1053). 
Dla sprawnego i elastycznego zarządzania budżetem w trakcie roku budżetowego ustawodawca wprowadził do ustawy o finansach publicznych przepisy upoważniające organ wykonawczy j.s.t. do zmiany budżetu z mocy prawa, czy też na podstawie upoważnienia organu stanowiącego. Przykładowo dokonywanie zmian w planie dochodów i wydatków przez organ wykonawczy, o których mowa w art. 257 i 258 u.f.p., będą w istocie zmianą budżetu, ponieważ plan dochodów i wydatków stanowią istotną jego część. W praktyce plan ten posiada formę załączników do uchwały budżetowej.

Obok powołanych przepisów funkcję uelastycznienia budżetu oraz podstawę do jego zmiany przez organ wykonawczy stanowią przepisy z zakresu rezerw budżetowych. W szczególności są to art. 222 ust. 4 u.f.p. i art. 60 ust. 2 pkt 5 u.s.g. Zgodnie z ich dyspozycjami organ ten posiada wyłączne prawo do dysponowania rezerwami budżetu gminy (miasta). Co więcej, podział rezerw, o czym była już mowa, zawsze sprowadza się do przenoszenia limitów wydatków pomiędzy działami klasyfikacji budżetowej. W konsekwencji oznacza to zmianę planowanych kwot wydatków uprzednio ustalonych przez organ stanowiący w podjętej uchwale budżetowej. Ponadto, przyjęcie tezy - która będzie rozpatrywana w dalszej części glosy - że za pomocą środków z rezerw można tworzyć nowe zadania (nowe podziałki klasyfikacji budżetowej), stanowi akceptację dla ingerencji organu wykonawczego w strukturę wydatków budżetu określoną w art. 236 u.f.p., która jest jednocześnie kluczową zmianą tego budżetu, ale powiązaną z procesem jego wykonywania. Aczkolwiek zakres tej ingerencji jest ograniczony ustawowym limitem wysokości rezerw, a także celem (przeznaczeniem) rezerw celowych, który jest definiowany przez organ stanowiący w procesie stanowienia uchwały budżetowej ${ }^{8}$.

Reasumując, procesy zmiany i wykonywania budżetu nie zawsze są rozdzielone, a w wielu przypadkach zmiana budżetu może stanowić jego wykonywanie lub jest usprawnieniem (uelastycznieniem) tego wykonywania.

8 Zob. szerzej: M. Tyniewicki, Funkcjonowanie rezerw w budżecie jednostki samorzqdu terytorialnego - wybrane problemy praktyczne, „Przegląd Podatków Lokalnych i Finansów Samorządowych” 2014, nr 8, s. 30. 
W uzasadnieniu orzeczenia Sąd zakwestionował możliwość tworzenia nowego zadania w wyniku podziału rezerwy celowej. W sytuacji tej Burmistrz miasta mógł przeznaczyć środki na wspomniane zadanie „wykonanie przyłącza do fotoradaru i montaż masztu do fotoradaru”, o ile wcześniej Rada Miasta wprowadziłaby takie zadanie do budżetu w drodze zmiany uchwały budżetowej. Tym samym Sąd stwierdził, że w rozpatrywanej sprawie art. 222 ust. 4 u.f.p. nie miał żadnego znaczenia. Zaznaczyć tu tylko należy, że w uchwale budżetowej miasta na 2013 r. została ustanowiona rezerwa celowa na wydatki majątkowe.

Autor glosy nie zgadza się z powyższą argumentacją. Wydaje się, że z jednej strony Sąd zignorował treść art. 222 ust. 2 pkt 1 i art. 259 ust. 1 u.f.p., $\mathrm{z}$ drugiej pominął istotę procedury podziału rezerwy celowej jako elementu wykonywania budżetu j.s.t. O ile w doktrynie i orzecznictwie występują rozbieżności poglądów co do tworzenia nowych zadań przez organ wykonawczy w oparciu o rezerwę ogólną ${ }^{9}$, o tyle mniej wątpliwości w tym kontekście wywołuje rezerwa celowa. Zgodnie bowiem z art. 222 ust. 2 pkt 1 u.f.p. rezerwy celowe w budżecie j.s.t. mogą być tworzone na wydatki, których szczegółowy podział na pozycje klasyfikacji budżetowej nie może być dokonany w okresie opracowywania budżetu j.s.t. Tak więc podczas tworzenia rezerwy celowej (w procedurze podejmowania uchwały budżetowej na dany rok) znane jest jej ogólne przeznaczenie (cel), które określa organ stanowiący. Jednakże ze względu na ten duży stopień ogólności w momencie uchwalania budżetu niemożliwe jest przypisanie takich wydatków do konkretnych numerów podziałek klasyfikacji budżetowej. Dopiero w trakcie wykonywania budżetu organ wykonawczy dokonuje konkretyzacji przeznaczenia środków rezerwy celowej w drodze właściwego zarządzenia, na podstawie którego przenosi on limity wydatkowe z rezerwy do konkretnych podziałek klasyfikacji budżetowej. O ile więc można by się zastanawiać, czy w takim trybie dozwolone jest two-

9 Zob. szerzej: J.M. Salachna, Dokonywanie zmian w uchwale..., s. 343; R. Trykozko, Ustawa o finansach publicznych. Komentarz dla jednostek samorzqdu terytorialnego, Warszawa 2010, s. 340; wyrok WSA w Poznaniu z dnia 30 stycznia 2014 r., I SA/Po 1107/13; postanowienie NSA z dnia 19 października 2011 r., I OZ 773/11; uchwała Nr 19/1571/2011 Kolegium Regionalnej Izby Obrachunkowej w Poznaniu z dnia 28 września 2011 r. 
rzenie nowego działu i rozdziału klasyfikacyjnego w planie wydatków budżetu j.s.t., o tyle wątpliwości nie powinna budzić czynność wprowadzenia nowego paragrafu klasyfikacyjnego w ramach istniejącego już działu i rozdziału. Czynności taka stanowi nic innego jak dokonanie „szczegółowego podziału na pozycje klasyfikacji budżetowej” (art. 222 ust. 2 pkt 1 u.f.p.) oraz ,wykorzystanie (rezerwy celowej - przyp. aut.) zgodnie z klasyfikacją budżetową wydatków” (art. 259 ust. 1 u.f.p.). Tego typu sytuacja występuje $\mathrm{w}$ analizowanej sprawie: zmniejszenie kwoty wydatku (limitu wydatkowego) w dziale 758, rozdziale 75818 oraz zwiększenie kwoty wydatków w istniejącym dziale 754, rozdziale 75416, poprzez utworzenie nowego zadania majątkowego.

Abstrahując od tej konkretnej sytuacji, opisywana czynność podziału rezerwy celowej byłaby jeszcze bardziej uzasadniona, gdyby budżet j.s.t. nie został uchwalony w pełnej szczegółowości, tj. z pominięciem paragrafów klasyfikacji budżetowej. Wówczas pełnego uszczegółowienia budżetu dokonałby organ wykonawczy w ramach procedury jego wykonywania, w tym procedury podziału rezerw celowych.

\section{4.}

Podsumowując, zdaniem autora glosy teza WSA w Poznaniu, iż Burmistrz w wyniku dokonanej czynności podziału rezerwy celowej poprzez jej przeznaczenie na nowe zadanie majątkowe (inwestycyjne) - „wykonanie przyłącza do fotoradaru i montaż masztu do fotoradaru” - którego Rada Miasta w budżecie nie przewidziała, przekroczył swoje kompetencje, nie znajduje uzasadnienia w świetle $\mathrm{z}$ art. 222 ust. 2 pkt 1 u.f.p. Każdorazowe występowanie do organu stanowiącego o zmianę budżetu polegającą na utworzeniu nowego zadania, a następnie rozdysponowanie rezerwy na to zadanie, stoi w sprzeczności z istotą rezerwy celowej, określonej przepisami ustawy o finansach publicznych i ustawy o samorządzie gminnym. Nie służy również funkcji elastyczności budżetu, którego instrumentami mają być rezerwy, oraz pozbawia organ wykonawczy wyłącznej kompetencji do podziału rezerw, w tym rezerw celowych. 


\section{Bibliografia:}

Ruśkowski E., Salachna J.M. (red.), Finanse publiczne. Komentarz praktyczny, ODDK, Gdańsk 2014.

Salachna J.M., Dokonywanie zmian w uchwale budżetowej jednostki samorzqdu terytorialnego, [w:] J.M. Salachna (red.), Budżet samorzq̨owy i wieloletnia prognoza finansowa - projektowanie, wykonywanie, sprawozdawczość, ODDK, Gdańsk 2014.

Trykozko R., Ustawa o finansach publicznych. Komentarz dla jednostek samorzq̨du terytorialnego, Taxpress, Warszawa 2010.

Tyniewicki M., Funkcjonowanie rezerw w budżecie jednostki samorzqdu terytorialnego - wybrane problemy praktyczne, „Przegląd Podatków Lokalnych i Finansów Samorządowych” 2014, nr 8, s. 29-35. 